\title{
The Preliminary Research of Sea Water District Heating and Cooling for Tallinn Coastal Area
}

\author{
Allan Hani, Teet-Andrus Koiv \\ Environmental Department, Tallinn University of Technology, Tallinn, Estonia. \\ Email: allan.hani@rkas.ee
}

Received May $2^{\text {nd }}, 2012$; revised June $1^{\text {st }}$, 2012; accepted June $8^{\text {th }}, 2012$

\begin{abstract}
This paper describes possibilities to utilize sea water for district heating and cooling purposes in Tallinn costal area. The sea water temperature profiles and suitability of heating and cooling generation are studied for continental climatic conditions. The district network study bases on 21 buildings located near to the Gulf of Finland. Industrial reversible heat pump technology is selected to cover heating and cooling loads for the new buildings. Combination of existing district heating and heat pump technology is considered for existing buildings. The results show possibilities, threats and need for further research of the sea water based heat pump district network implementation.
\end{abstract}

Keywords: District Heating; Cooling; Sea Water; Heat Pump; Renewable Energy; Office Building

\section{Introduction}

The European Union 20-20-20 targets emphasize implementation of renewable energy sources in member states energy balances. Sea water is a large renewable energy source, which can be combined with reversible heat pump technology to produce both thermal and cooling energy. The working principle is similar to geothermal energy production, but the sea water allows utilization of free cooling during spring and autumn period. The heat pump technology is studied widely around the World. A comprehensive review of heat pump systems implementation possibilities in different fields and also recent improvement with coefficient of performance (COP) is presented [1]. The heat pump technology rapid growth in $2005-2010$ is documented $[2,3]$. The sea water electrically driven heat pump technology feasibility is compared with conventional district heating, in case the network radius is less than $5 \mathrm{~km}$ [4]. The calculation includes coal-fired plants electricity production losses and pumping costs. When the electricity is produced from natural gas, the radius degreases. Feasibility of different district heating and cooling production options is studied [5]. The life cycle costs are included (installation, system operating, maintenance costs). The sea water district heating and cooling is 1.5 times more expensive in China, due to relatively low coal-produced electrical energy price. All the economic calculations shall be carried out project by project separately. Indirect sea water cooling for Japan commercial buildings is researched [6]. Thermal storage tank of $4500 \mathrm{~m}^{3}$ is used. Storage tank covers $32 \%$ of the cooling peak load. Difference of water temperature utilization is $7 \mathrm{~K}\left(5^{\circ} \mathrm{C}-12^{\circ} \mathrm{C}\right)$. Cooling capacity of chillers is 2.3 MW. Large advantage in maintenance costs was found also a slight saving in initial cost was found. Boiler plant and heat pump technology is compared by quasidynamic energy-saving calculation [7]. The static calculations authors presented earlier the same year (2010) underestimated the feasibility of sea water district heating and cooling by $20 \%$. Similar study was carried out in Japan [8]. Compared to conventional systems (cooling tower and heating boiler plant) the saving of $29 \%$ was received for district cooling and 5\% for district heating. In Sweden the short and long term impacts of heat pump technology are compared with district heating systems [9]. Totally $6 \mathrm{TWH}$ thermal energy was produced in Sweden year 2007. Energy optimization tool MODEST was used for systems modelling. In a total thermal energy balance of Sweden, still the heat pump systems for district heating will be developed in small scale, combined heat and power from renewable energy resources (CHP) is preferred. Nevertheless, in our Estonian case the share of cooling energy of selected buildings is higher than thermal energy. Therefore in certain costal areas the free cooling from sea water could be feasible and ecologically friendly. In Germany the de-nuclearization as a process is started [10]. Renewable energy storage and transportation possibilities are presented in the article. The problems are laid on the table, but solutions are still fully open. In Greece the cooling dominates 
widely over the heating demand [11]. The proposed systems are vice versa to ours solutions - extra cooling towers are used to cover peak cooling loads. Heating and average cooling demand is proposed to be produced with heat pumps. Groundwater open loop heat pump systems are researched [12]. Water storage tank is used either on chilled water or groundwater side. In chilled water side $10 \%$ saving was received due to better COP. The study of environmental impacts of different heat sources (coal boiler, gas boiler and heat pump with different COP) [13]. All the heat pumps with COP $>2.5$ are more environmentally friendly to install than gas boilers. The coal boilers should be avoided. Low temperature heating will give better COP [14]. In our sea water district heating and cooling case the new buildings shall have low temperature heating and in existing buildings the high temperature district heating will be combined with heat pump system. Different connection possibilities are presented in research of combining existing district heating and new heat pump technology [15]. The heat pump heat exchangers optimization study [16] gives a comprehensive overview of the heat exchanger selection principles. Different new implementation options and heat pump refrigerants are presented in exhaustive articles [17-23].

The feasibility and technical possibilities are closely related to different boundary parameters:

1) Sea water temperature profile and salinity;

2) Outdoor climatic conditions;

3) Coastal area geology;

4) Possibilities to construct the sea water and district network pipelines;

5) Heating and cooling loads of the connectable buildings;

6) Temperature regimes of the pipelines;

7) Secure energy supply.

In current study these different aspects are analysed. The threats and possibilities are presented of the sea water district heating and cooling for Tallinn coastal area.

\section{Methods}

\subsection{Gulf of Finland Parameters}

The water and thermal processes in Gulf of Finland are continuously monitored among HELCOM project. Scientific articles $[24,25]$ are written about the sea water parameters by Scandinavian and Estonian scientists.

All the measurements reported to HELCOM have to comply with survey program COMBINE requirements. The information about requirements is available:

http://www.helcom.fi/groups/monas/CombineManual/en GB/main/

Due to the salinity of the gulf water the ice formation will appear $<-0.4^{\circ} \mathrm{C}$.

Average ice thickness is $31 \mathrm{~cm}$, very rare thickness >
50 - $60 \mathrm{~cm}$ (absolute maximum $1.2 \mathrm{~m}$ in a 150 years).

The sea water temperature and profile are analysed for the sea water heat pump plant possibility. The average depth profile of Gulf of Finland is presented in Table 1.

Depth of the gulf is shallow-averagely it will increase $5 \mathrm{~m}$ by additional distance of $1 \mathrm{~km}$ from the coast. Economically it would be efficient to search deeper locations in costal area $(<500 \mathrm{~m})$. In following Figure 1 the sea water temperature profile during the year is presented. The data bases on Gulf of Finland monitoring station F3 info. Monthly average as well minimum and maximum temperatures are presented in correlation of sea depth.

There is a wide variation of temperature during the year in a whole depth profile. In combination of distance $<500 \mathrm{~m}$ and depth $-20 \mathrm{~m}$ the temperature range will be between $-0.31^{\circ} \mathrm{C}$ in winter to $16.6^{\circ} \mathrm{C}$ in summer.

\subsection{Outdoor Climatic Conditions}

Tallinn area external air duration diagram is presented in Figure 2.

In our case outdoor climatic conditions and other reference buildings design information is taken as a basis for dimensioning the sea water district heating and cooling plant loads. Minimum temperature for heating load calculation is $-22^{\circ} \mathrm{C}$ to assure $21^{\circ} \mathrm{C}$ in buildings. Cooling load design parameters are $+27^{\circ} \mathrm{C}$ and $50 \%$ relative humidity to assure $+24^{\circ} \mathrm{C}$ in buildings.

Table 1. Average gulf of Finland depth profile.

\begin{tabular}{cc}
\hline $\begin{array}{c}\text { Distance from coast } \\
\mathrm{m}\end{array}$ & $\begin{array}{c}\text { Depth (sea) } \\
\mathrm{m}\end{array}$ \\
\hline 500 & 20 \\
1500 & 25 \\
3200 & 30 \\
4000 & 35 \\
5500 & 40 \\
\hline
\end{tabular}

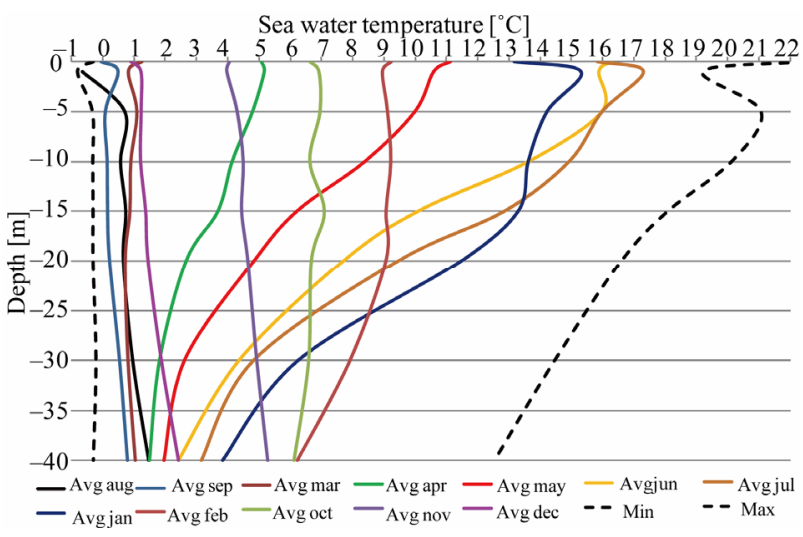

Figure 1. Monitoring station F3 measurement results. 


\section{Results and Discussion}

\subsection{Case Study}

Based on the local area development plan 21 buildings (see Table 2) are included to the research from Port of Tallinn area. There are existing buildings, but a majority is considered to be erected. The heating and cooling consumption total network is planned $<1 \mathrm{~km}$ radius from the coast.

In preliminary stage $80 \mathrm{~W} / \mathrm{m}^{2}$ public area for heating load calculations and $100 \mathrm{~W} / \mathrm{m}^{2}$ public area for cooling calculations was calculated. These values include transportation losses 5\% for cooling and $10 \%$ for thermal energy. $60 \mathrm{~W} / \mathrm{m}^{2}$ public area is calculated for Building no 17 cooling demand.

Total 14.3 MW heating and 16.4 MW cooling load is calculated. Simultaneous factor of 0.85 is applied to the calculation results. The plant maximum thermal capacity is $12 \mathrm{MW}$ and cooling capacity $14 \mathrm{MW}$. Plant shall be located beside Gulf of Finland

The Tallinn costal area depth profile is presented in following Figure 3. The depth of $25 \mathrm{~m}$ is located $500 \mathrm{~m}$ from the area. Flow pipe shall be directed there. Return pipe can be located near to the coast.

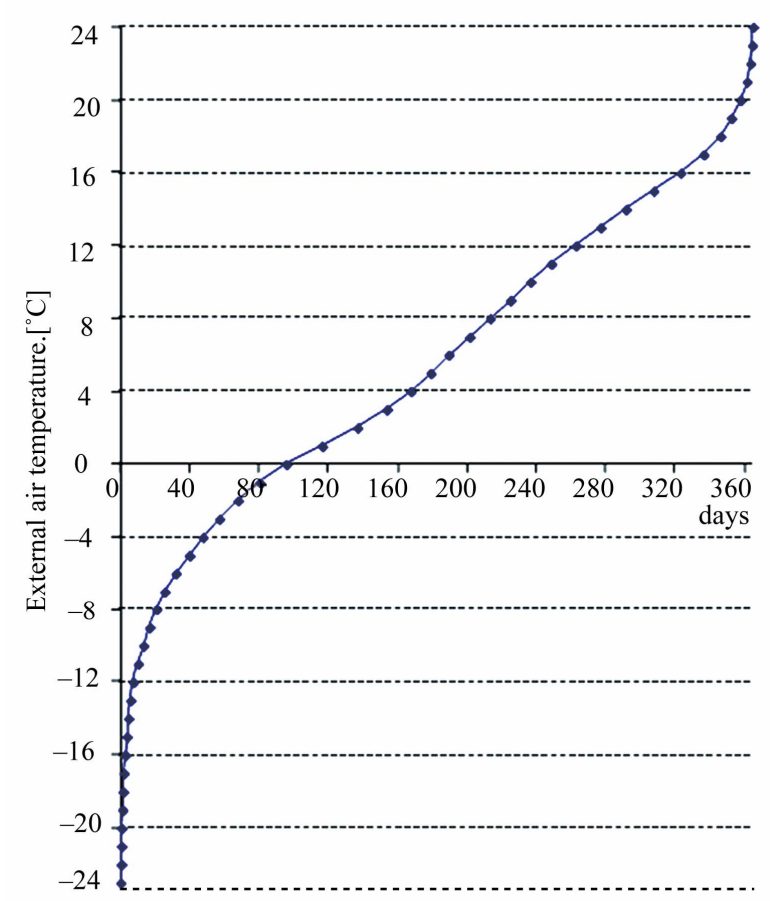

Figure 2. Tallinn external air duration diagram.

Table 2. Heating and cooling load calculation.

\begin{tabular}{|c|c|c|c|c|c|}
\hline $\begin{array}{c}\text { Building } \\
\text { no }\end{array}$ & $\begin{array}{l}\text { Building height } \\
\mathrm{m}\end{array}$ & $\begin{array}{l}\text { Storeys above } \\
\text { ground }\end{array}$ & $\begin{array}{l}\text { Public area } \\
\mathrm{m}^{2}\end{array}$ & $\begin{array}{c}\text { Cooling demand } \\
\text { kW }\end{array}$ & $\begin{array}{l}\text { Heating demand } \\
\text { kW }\end{array}$ \\
\hline 1 & 24 & 6 & 8764 & 876 & 701 \\
\hline 2 & 24 & 6 & 18,870 & 1887 & 1510 \\
\hline 3 & 24 & 6 & 1458 & 146 & 117 \\
\hline 4 & 24 & 6 & 3564 & 356 & 285 \\
\hline 5 & 24 & 6 & 5780 & 578 & 462 \\
\hline 6 & 18 & 5 & 5198 & 520 & 416 \\
\hline 7 & 11 & 2 & 2340 & 234 & 187 \\
\hline 8 & 18 & 5 & 8775 & 878 & 702 \\
\hline 9 & 24 & 6 & 2268 & 227 & 181 \\
\hline 10 & 24 & 6 & 2430 & 243 & 194 \\
\hline 11 & 24 & 6 & 10,260 & 1026 & 821 \\
\hline 12 & 24 & 6 & 5049 & 505 & 404 \\
\hline 13 & 24 & 6 & 4860 & 486 & 389 \\
\hline 14 & 20 & 5 & 24,500 & 2450 & 1960 \\
\hline 15 & 16 & 4 & 4250 & 425 & 340 \\
\hline 16 & 19 & 5 & 11,200 & 1120 & 896 \\
\hline 17 & - & 4 & 37,221 & 2233 & 2978 \\
\hline 18 & 19 & 5 & 10,500 & 1050 & 840 \\
\hline 19 & 19 & 5 & 2200 & 220 & 176 \\
\hline 20 & 19 & 5 & 5250 & 525 & 420 \\
\hline 21 & 22 & 5 & 3700 & 370 & 296 \\
\hline
\end{tabular}




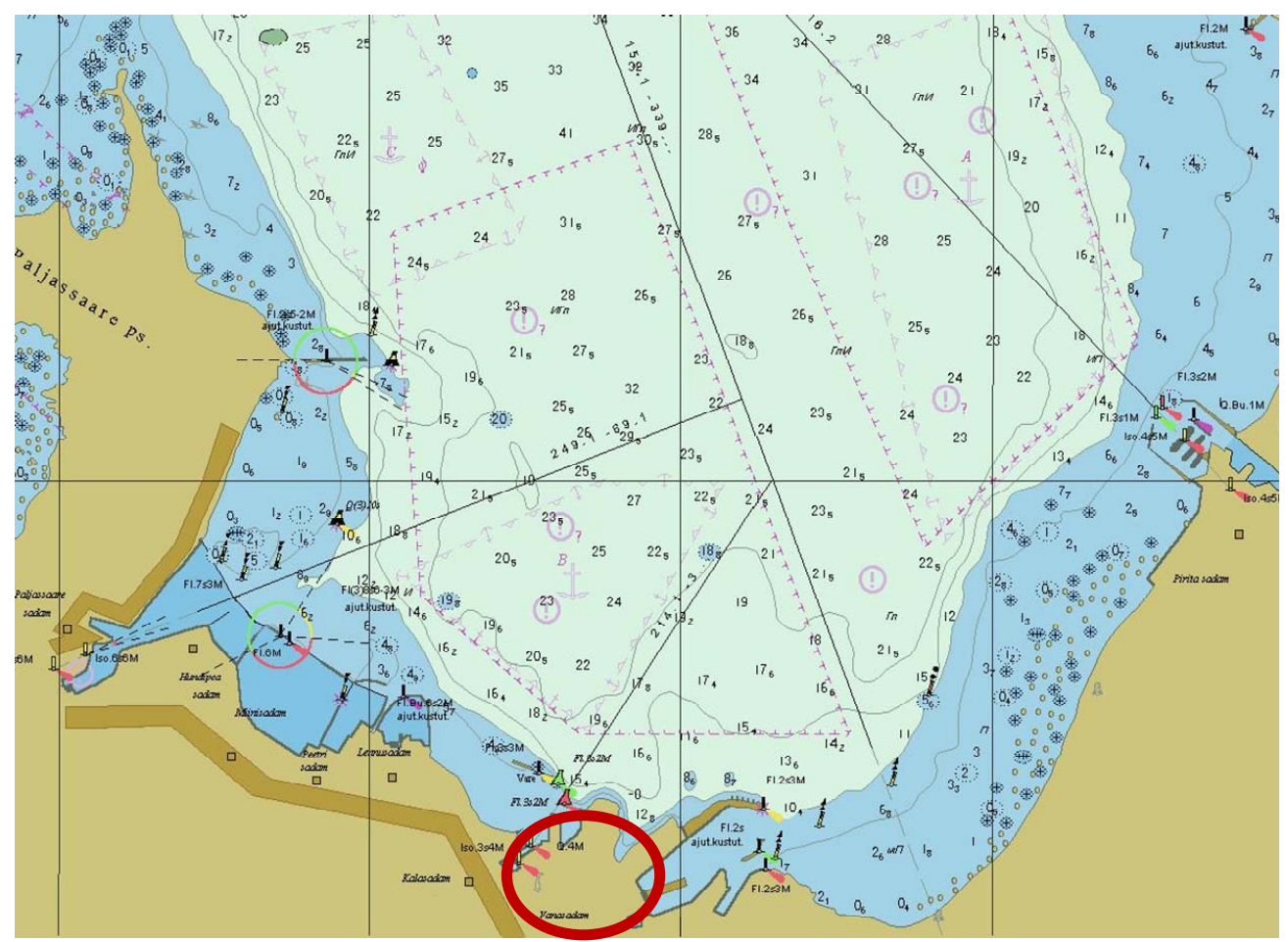

Figure 3. Tallinn coastal area sea water profile.

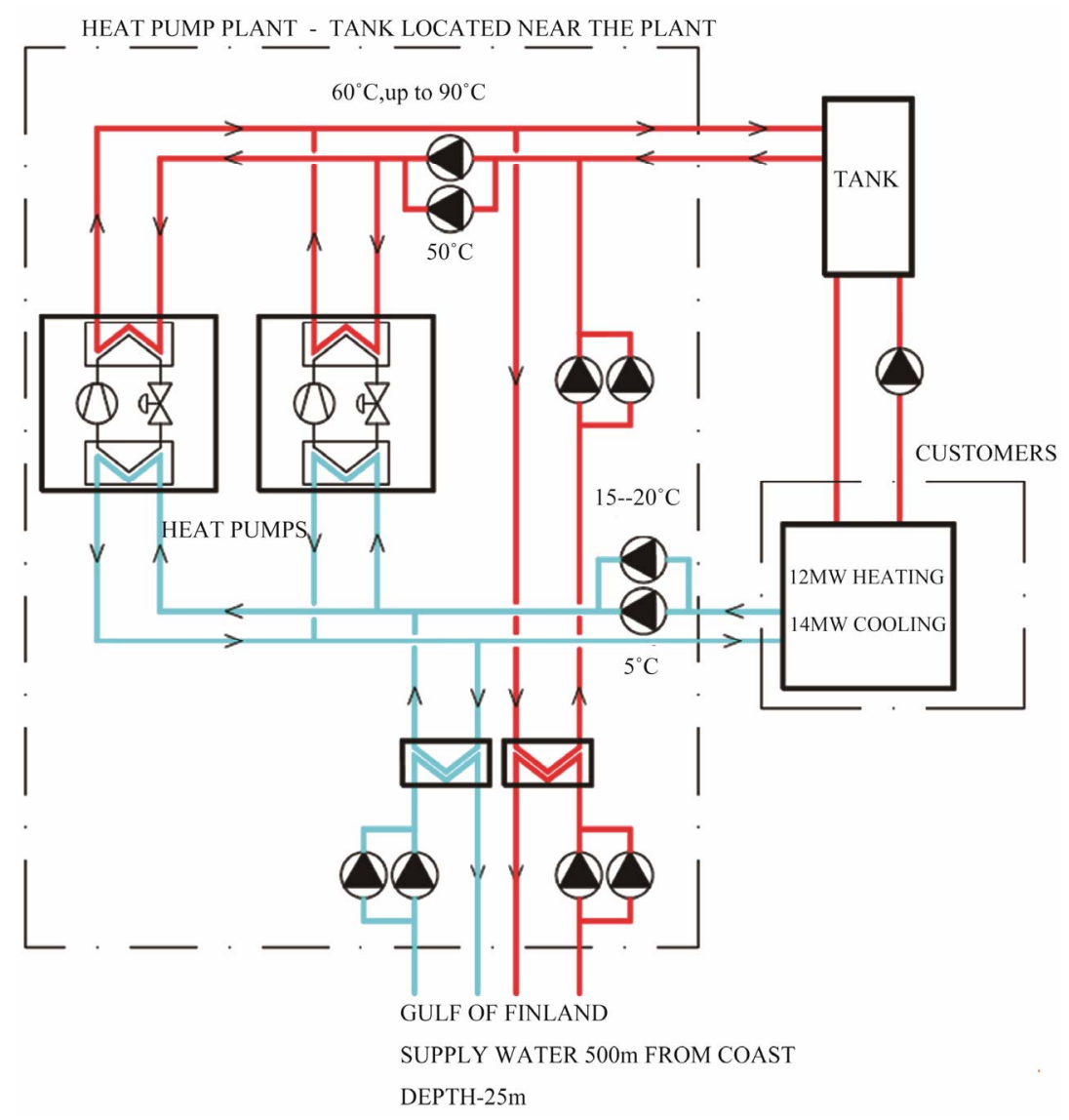

Figure 4. The principle schematic of sea water district heating and cooling plant. 


\subsection{Technology}

Two industrial heat pumps (e.g. Uniturbo 34FY a'8.0 MW) with high condenser water outlet temperatures for heating and with cooling operation are considered to cover the heating and cooling demand of the buildings. The principle schematic is presented in Figure 4.

\subsubsection{Heating Mode Operation}

Supply water temperature to district network $60^{\circ} \mathrm{C}-90^{\circ} \mathrm{C}$ $\left(70^{\circ} \mathrm{C}\right)$.

Return water temperature from district network $50^{\circ} \mathrm{C}$.

Thermal storage tank is to provide district heating network temperature stability and prevent freezing of the evaporator side of return sea water. $3600 \mathrm{~m}^{3}$ tank could provide up to 7 days thermal energy ( $\mathrm{DT}=20 \mathrm{~K}$ ).

Sea water $\mathrm{DT}=2 \mathrm{~K}\left(0^{\circ} \mathrm{C} / 2^{\circ} \mathrm{C}\right)$.

The new buildings must be deigned for low temperature heating $\left(55^{\circ} \mathrm{C} / 40^{\circ} \mathrm{C}\right)$ to allow max efficiency of the heat pump plant. For existing buildings $\left(80^{\circ} \mathrm{C} / 60^{\circ} \mathrm{C}\right.$ or $70^{\circ} \mathrm{C} / 50^{\circ} \mathrm{C}$ ) combination of heat pump plant and district heating shall be considered.

District heating network shall be insulated to provide minimum thermal losses of the system.

\subsubsection{Cooling Mode Operation}

Supply water temperature to district network $5^{\circ} \mathrm{C}$. Return water temperature from district network $15^{\circ} \mathrm{C}-20^{\circ} \mathrm{C}$.

Sea water temperature $<4^{\circ} \mathrm{C}$.

Completely free-cooling;

Sea water temperature $4^{\circ} \mathrm{C}-10^{\circ} \mathrm{C}$.

Pre-cooling with sea water + compressor cooling;

Sea water temperature $>10^{\circ} \mathrm{C}$.

Only compressor cooling (free cooling heat exchangers are equipped with bypasses).

Due to fact that summer period soil temperature in 1.5 $\mathrm{m}$ depth is $10^{\circ} \mathrm{C}$ it is not necessary to insulate the return pipe of the district cooling network. Supply pipe is insulated with $10 \mathrm{~cm}$ nowadays heat insulation material.

The titanium heat exchangers allow usage of the soft water in distribution network while problematic salty sea water handling will be done in open central circuit.

\subsection{Comparable Research and Risk Definition}

Based on the reference projects studied and referred in introduction part of current study the sea water for district heating and cooling is a favourable renewable energy source. Still there are several matters to be considered before the real investment decision could be made.

Environmental impact study is required before any of the projects will be executed. In addition to evaluation of the deep zone cold water pumping, the analysis of recycling the sea water back to lower sea water zone with higher and lower temperatures should be carried out.
Possibilities to use old underground tunnels, etc. must be studied to find economically reasonable solutions for district network construction.

The thermal storage tank size optimization is necessary to do as it affects both the stability of the district heating network and economical possibilities to continue with the combined plant design.

There is a risk to have too low temperatures in evaporation side during cold winter period which will cause shut-off the heat pumps. A storage tank helps to overcome this, but can not fully prevent it, if the cold period will last longer than designed. The design parameters must be carefully considered.

Also minimum altitudes between heat exchangers and water resource level should be designed.

Centralized district heating and cooling plant, heat exchangers, pumping station is normally less expensive than decentralised systems altogether.

Centralized system has less maintenance problems.

Usually conventional cooling systems utilize electrical energy, which in Estonia is produced from oil-shale. Sea water is a huge cold water resource, so free cooling can be used.

\section{Conclusions}

In the current study possibilities of sea water utilization as thermal and cooling energy resource are studied in continental climate area. The Gulf of Finland as well as Tallinn outdoor climate parameters were taken to inputs for the study.

There are 21 office buildings selected from real development project with $14 \mathrm{MW}$ cooling and $12 \mathrm{MW}$ heating energy demand.

Possible connection diagram is presented for the buildings. The most important concern is to provide thermal energy also in low sea water temperature conditions, where the return glycol-water mixture from heat pump can cause sea water to freeze inside the heat exchanger. The selection of sea water pipes routing shall be studied in future to provide more the most effective conditions. Also closed-loop pipe system shall be studied to prevent the freezing problem (glycol-water mixture inside the piping).

Low temperature $\left(55^{\circ} \mathrm{C} / 40^{\circ} \mathrm{C}\right)$ heating shall be designed for new buildings. For existing buildings the new district heating system must be combined with old city district heating network.

The summer period district cooling solution is simpler. Three possible control modes are applied-free cooling is preferred and automation system shall be designed according to this requirement.

The parallel heating and cooling operation mode can be applied with 2 heat pumps. It is important mostly in spring and autumn season, where different buildings and 
even building sides can have both, cooling and heating demand.

The optimization of systems and economical feasibility study should be carried out before to continue with research and real design. Furthermore, trigeneration versus sea water district heating and cooling evaluation is needed to be researched.

\section{Acknowledgements}

Estonian Ministry of Education and Research is greatly acknowledged for funding and supporting this study. European Social Foundation financing task 1.2.4 Cooperation of Universities and Innovation Development, Doctoral School project "Civil Engineering and Environmental Engineering” code 1.2.0401.09-0080 has made publishing of this article possible.

\section{REFERENCES}

[1] K. J. Chua, S. K. Chou and W. M. Yang, "Advantages in Heat Pump Systems: A Review,” Applied Energy, Vol. 87, No. 12, 2010, pp. 3611-3624. doi:10.1016/j.apenergy.2010.06.014

[2] J. W. Lund, D. H. Freeston and T. L. Boyd, "Direct Application of Geothermal Energy: 2005 Worldwide Review," Geothermics, Vol. 34, No. 6, 2005, pp. 691-727. doi:10.1016/j.geothermics.2005.09.003

[3] J. W. Lund, D. H. Freeston and T. L. Boyd, "Direct Utilization of Geothermal Energy 2010 Worldwide Review,” Geothermics, Vol. 40, No. 3, 2010, pp. 159-180. doi:10.1016/j.geothermics.2011.07.004

[4] H. W. Shu, D. M. Lin, X. L. Li and Y. X. Zhu, "Energy-Saving Judgment of Electric-Driven Seawater Source Heat Pump District Heating System over Boiler House District Heating System,” Energy and Buildings, Vol. 42, No. 6, 2010, pp. 889-895. doi:10.1016/j.enbuild.2010.01.001

[5] H. W. Shu, D. M. Lin, C. H. Zhang and Y. X. Zhu, "Study on the Decision-Making of District Cooling and Heating Systems by Means of Value Engineering," Renewable Energy, Vol. 35, No. 9, 2010, pp. 1929-1939. doi:10.1016/j.renene.2010.01.021

[6] Y.-H. Song, Y. Akashi and J.-J. Yee, "Effects of Utilizing Seawater as a Cooling Source System in a Commercial Complex,” Energy and Buildings, Vol. 39, No. 10, 2007, pp. 1080-1087. doi:10.1016/j.enbuild.2006.11.011

[7] H. W. Shu, D. M. Lin, X. L. Li and Y. X. Zhu, "Quasi-Dynamic Energy-Saving Judgment of ElectricDriven Seawater Source Heat Pump District Heating System over Boiler House District Heating System,” Energy and Buildings, Vol. 42, No. 12, 2010, pp. 2424-2430. doi:10.1016/j.enbuild.2010.08.012

[8] T. Nagota, Y. Shimoda and M. Mizuno, "Verification of the Energy-Saving Effect of the District Heating and Cooling System-Simulation of an Electric-Driven Heat Pump System,” Energy and Buildings, Vol. 40, No. 5, 2008, pp. 732-741. doi:10.1016/j.enbuild.2007.05.007
[9] M. Eriksson and L. Vamling, "Future Use of Heat Pumps in Swedish District Heating Systems: Short- and LongTerm Impact of Policy Instruments and Planned Investments," Applied Energy, Vol. 84, No. 12, 2007, pp. 12401257. doi:10.1016/j.apenergy.2007.02.009

[10] C.-J. Winter, "After Nuclear Has Gone: Energy in Germany," International Journal of Hydrogen Energy, Vol. 37, No. 1, 2012, pp.1-5. doi:10.1016/j.ijhydene.2011.08.001

[11] Z. Sagia, C. Rakopoulos and E. Kakaras, "Cooling Dominated Hybrid Ground Source Heat Pump System Application,” Applied Energy, Vol. 94, 2012, pp. 41-47. doi:10.1016/j.apenergy.2012.01.031

[12] S. L. Russo, G. Taddia, G. Baccino and V. Verda, "Different Design Scenarios Related to an Open Loop Groundwater Heat Pump in a Large Building: Impact on Subsurface and Primary Energy Consumption,” Energy and Buildings, Vol. 43, No. 2-3, 2011, pp. 347-357. doi:10.1016/j.enbuild.2010.09.026

[13] C. M. Chen, Y. F. Zhang and L. J. Ma, “Assessment for Central Heating Systems with Different Heat Sources: A Case Study,” Energy and Buildings, Vol. 48, 2012, pp. 168-174. doi:10.1016/j.enbuild.2012.01.025

[14] V. Verda, G. Baccino, A. Sciacovelli and S. L. Russo, "Impact of District Heating and Groundwater Heat Pump Systems on the Primary Energy Needs in Urban Areas," Applied Thermal Engineering, Vol. 40, 2012, pp. 18-26. doi:10.1016/j.applthermaleng.2012.01.047

[15] Y. Wang and Y. F. Zhang, "Analysis of the Dilatancy Technology of District Heating System with High-Temperature Heat Pump," Energy and Buildings, Vol. 47, 2012, pp. 230-236. doi:10.1016/j.enbuild.2011.11.038

[16] B. David, J. Ramousse and L. G. Luo, “Optimization of Thermoelectric Heat Pumps by Operating Condition Management and Heat Exchanger Design,” Energy Conversion and Management, Vol. 60, 2012, pp. 125-133. doi:10.1016/j.enconman.2012.02.007

[17] S. Okamoto, "A Heat Pump System with a Latent Heat Storage Utilizing Seawater Installed in an Aquarium," Energy and Buildings, Vol. 38, No. 2, 2006, pp. 121-128. doi:10.1016/j.enbuild.2005.04.004

[18] K. Bakirci and B. Yuksel, "Experimental Thermal Performance of a Solar Source Heat-Pump System for Residential Heating in Cold Climate Region," Applied Thermal Engineering, Vol. 31, No. 8-9, 2011, pp. 1508-1518. doi:10.1016/j.applthermaleng.2011.01.039

[19] K. Hirata and H. Kakiuchi, "Energy Saving for Ethylene Process by Adsorption Heat Pump," Applied Thermal Engineering, Vol. 31, No. 13, 2011, pp. 2115-2122. doi:10.1016/j.applthermaleng.2011.03.031

[20] W. E. TeGrotenhuis, P. H. Humble and J. B. Sweeney, "Simulation of a High Efficiency Multi-Bed Adsorption Heat Pump,” Applied Thermal Engineering, Vol. 37, 2012, pp. 176-182. doi:10.1016/j.applthermaleng.2011.11.012

[21] B. T. Austin and K. Sumathy, "Transcritical Carbon Dioxide Heat Pump Systems: A Review," Renewable and Sustainable Energy Reviews, Vol. 15, No. 8, 2011, pp. 4013-4029. doi:10.1016/j.rser.2011.07.021

[22] K. Yasukawa and S. Takasugi, "Present Status of Under- 
ground Thermal Utilization in Japan," Geothermics, Vol. 32, No. 4-6, 2003, pp. 609-618.

doi:10.1016/j.geothermics.2003.07.011

[23] A. Hall, J. A. Scott and H. Shang, "Geothermal Energy Recovery from Underground Mines,” Renewable and Sustainable Energy Reviews, Vol. 15, No. 2, 2011, pp. 916924. doi:10.1016/j.rser.2010.11.007

[24] B. Jonsson, K. Doos, J. Nycander and P. Lundberg,
"Standing Waves in the Gulf of Finland and Their Relationship to the Basin-Wide Baltic Seiches,” Journal of Geophysical Research, Vol. 113, 2008, Article ID: C03004. doi:10.1029/2006JC003862

[25] T. Liblik and U. Lips, "Characteristics and Variability of the Vertical Thermohaline Structure in the Gulf of Finland in Summer,” Boreal Environment Research, Vol. 16, 2011, pp. 73-83. 